\title{
LETTER
}

\section{Sapphirine + quartz assemblage from Ganguvarpatti: diagnostic evidence for ultrahigh-temperature metamorphism in central Madurai Block, southern India}

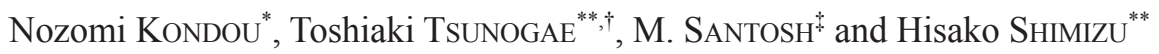 \\ ${ }^{*}$ College of Natural Sciences, University of Tsukuba, Ibaraki 305-8571, Japan \\ ** Graduate School of Life and Environmental Sciences (Earth Evolution Sciences), \\ University of Tsukuba, Ibaraki 305-8572, Japan \\ ${ }^{\dagger}$ Department of Geology, University of Johannesburg, Auckland Park 2006, \\ Republic of South Africa \\ ${ }^{\ddagger}$ Department of Natural Environmental Science, Faculty of Science, \\ Kochi University, Akebono-cho 2-5-1, Kochi 780-8520, Japan
}

\begin{abstract}
We report the finding of sapphirine + quartz equilibrium assemblage in an orthopyroxene-sapphirine granulite from Ganguvarpatti in southern India, providing diagnostic evidence for ultrahigh-temperature (UHT) metamorphism in the central Madurai Block. The sapphirine-quartz-bearing rock is composed of coarse-grained $(\sim 3 \mathrm{~mm})$ porphyroblastic orthopyroxene and sapphirine which were probably stable phases during the peak UHT condition within the stability field of sapphirine + quartz. The rock also contains corona textures such as orthopyroxene + sapphirine + cordierite and orthopyroxene + cordierite symplectites formed by post-peak decompression. The porphyroblastic sapphirine contains rare inclusions of quartz. The equilibrium sapphirine + quartz reported here is regarded as a diagnostic indicator of peak metamorphism at $T>1000{ }^{\circ} \mathrm{C}$ and confirms the formation and exhumation of ultra-hot orogens during the accretionary history of the Madurai Block related to the Pacific-type orogeny and final collisional assembly of the Gondwana supercontinent in the Late Neoproterozoic-Cambrian.
\end{abstract}

Keywords: Sapphirine + quartz, Ultrahigh-temperature metamorphism, Ganguvarpatti, Madurai Block, Southern India, Gondwana supercontinent

\section{INTRODUCTION}

Available experimental and phase equilibrium studies of high-grade metamorphic rocks demonstrate that the direct contact of sapphirine and quartz is a robust evidence of $T>1000{ }^{\circ} \mathrm{C}$ ultrahigh-temperature (UHT) metamorphism (e.g., Hensen and Green, 1973; Bertrand et al., 1991; Harley, 1998; Kelsey et al., 2004; Kelsey, 2008). This is consistent with the observations that the assemblage has been reported from many granulite terranes of different ages that underwent extreme crustal metamorphism (e.g., Santosh et al., 2007; Kelsey, 2008 and references therein). The southern granulite terrane (SGT) in India is characterized by the occurrence of Late Neoproterozoic to Early Cambrian (Santosh et al., 2003, 2006; Collins et al., 2007,

doi:10.2465/jmps.090607

T. Tsunogae, tsunogae@geol.tsukuba.ac.jp Corresponding author M. Santosh, santosh@cc.kochi-u.ac.jp and references therein) high-grade metamorphic rocks that underwent $T>900{ }^{\circ} \mathrm{C}$ peak metamorphism related to the collisional orogeny during the final stage of assembly of Gondwana supercontinent (Santosh et al., 2009a, $2009 \mathrm{~b}$ and references therein). The peak UHT metamorphism in this terrane is supported by the occurrence of some key mineral assemblages such as orthopyroxene + sillimanite + quartz, spinel + quartz, Al-rich orthopyroxene, and mesoperthite as well as sapphirine + quartz (e.g., Tateishi et al., 2004; Sajeev et al., 2004; Morimoto et al., 2004; Ishii et al., 2006; Tadokoro et al., 2007, 2008; Tsunogae et al., 2008a; Shimizu et al., 2009). In spite of the widespread occurrence of UHT metamorphic rocks in southern India, the equilibrium sapphirine + quartz assemblage has been reported only from one locality (Rajapalaiyam in the southern Madurai Block, Tateishi et al., 2004; Tsunogae and Santosh, 2006, 2009; Braun et al., 2007). It is therefore still not known whether the $T>1000$ 


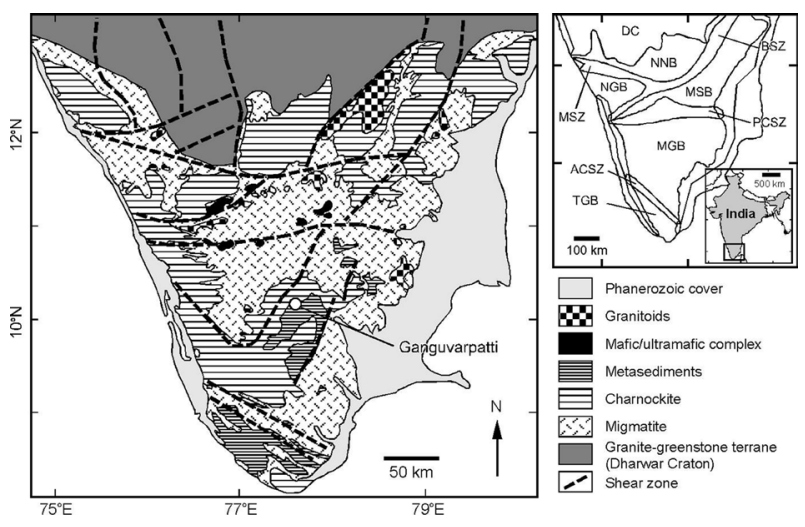

Figure 1. Simplified geological map of southern India (after Santosh and Sajeev, 2006) with Ganguvarpatti and Rajapalaiyam localities discussed in this paper. DC, Dharwar Craton; MGB, Madurai Block; MSB, Madras Block; NNB, Northern Block; NGB, Nilgiri Block; TGB, Trivandrum Block; MSZ, Moyar Shear Zone; BSZ, Bhavani Shear Zone; PCSZ, Palghat-Cauvery Suture Zone; ACSZ, Achankovil Shear Zone.

${ }^{\circ} \mathrm{C}$ UHT metamorphism is a regional event throughout the SGT, or a local episode possibly related to the infiltration of $\mathrm{CO}_{2}$-rich fluids (e.g., Santosh and Omori, 2008; Tsunogae et al., 2008b).

In this study, we carried out detailed petrographic studies on sapphirine-bearing granulites from Ganguvarpatti (e.g., Mohan et al., 1985) in the Madurai Block, a key locality among the various UHT localities in the SGT because of its extremely high-temperature peak metamorphism $\left(T \sim 1000{ }^{\circ} \mathrm{C}\right)$ and various post-peak decompression textures reported in a number of studies (e.g., Sajeev et al., 2004; Tamashiro et al., 2004), although the most diagnostic assemblage of sapphirine + quartz has not been reported from this locality. Our investigations led to the discovery of sapphirine + quartz equilibrium assemblage in an orthopyroxene-sapphirine granulite from this locality, and is the second finding of sapphirine + quartz from the SGT. Below we will summarize the petrologic and mineral chemical characters of the sapphirine-quartzbearing rock, based on which we propose a revised $P-T$ path for the central Madurai Block. We also discuss the implications for the generation and exhumation of ultrahot orogens during the subduction-collision tectonics associated with the final assembly of the Gondwana supercontinent.

\section{PETROGRAPHY AND MINERAL CHEMISTRY}

The equilibrium sapphirine + quartz assemblage, although reported from a number of localities including from Gondwana collisional orogens (e.g., Tateishi et al., 2004; Sajeev and Osanai, 2004), usually occurs as a rare microstructure within a thin section. In this study we examined more than twenty rock samples and thirty thin sections from Ganguvarpatti before we found this equilibrium assemblage in stable coexistence. We summarize below the petrography and mineral chemistry of the sample. Mineral name abbreviations are after Spear (1993). Chemical analyses of minerals were carried out using an electron microprobe analyzer (JEOL JXA8621) at the University of Tsukuba following the technique described in Tsunogae et al. (2008a). Representative compositions of minerals in the sample are given in Table 1(available online from http://www.jstage.jst.go.jp/browse/jmps).

The rock comprises orthopyroxene, sapphirine, biotite, cordierite, and kornerupine (Fig. 2). Rutile and plagioclase occurs as accessory minerals. The peak assemblage of the rock is orthopyroxene (Opx1) and sapphirine (Spr1) which occur as subidioblastic and coarse-grained

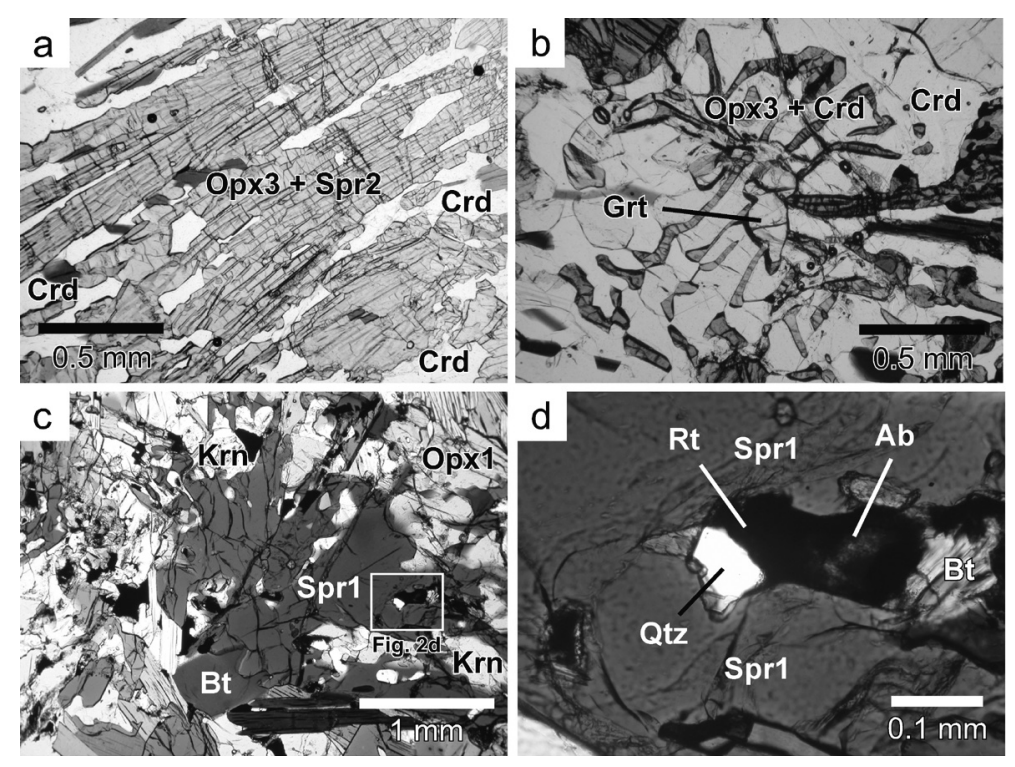

Figure 2. Thin section photomicrographs and backscattered electron images showing representative textures of $\mathrm{Mg}-\mathrm{Al}$ granulite from Ganguvarpatti. (a) Fan-like Opx3 + Spr $2+$ Crd symplectite formed by reaction (1). (b) Opx3 + Crd symplectite around garnet probably formed by reaction (2). (c) and (d) Coarse-grained porphyroblastic sapphirine (Spr1) that contains rare quartz inclusion. 


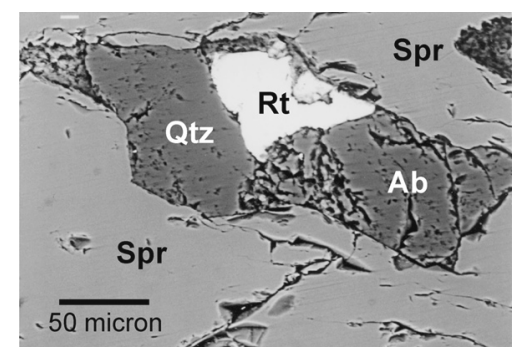

Figure 3. A back-scattered electron image showing detailed microstructure of sapphirine + quartz assemblage in sample MD1-1W.

( $3 \mathrm{~mm}$ ) minerals mantled by fine-grained symplectitic intergrowth of orthopyroxene (Opx3), sapphirine (Spr2), and cordierite (Fig. 2a). Although garnet ( $\mathrm{Alm}_{39-49} \operatorname{Prp}_{45-58}$ $\left.\mathrm{Grs}_{3-5} \mathrm{Sps}_{1-2}\right)$ is a dominant mineral in most Ganguvarpatti samples (e.g., Sajeev et al., 2004), it is absent in the sapphirine-quartz-bearing thin section. As the Opx3 + Spr2 + Crd symplectite has been regarded as a product of decompression due to the progress of reaction (1) mentioned below (e.g., Sajeev et al., 2004), all garnet grains in the sample were probably consumed by the progress of the following FMAS continuous reaction:

$$
\mathrm{Grt}=\mathrm{Opx} 3+\mathrm{Spr} 2+\mathrm{Crd}
$$

In garnet-bearing samples Opx $3+$ Crd symplectite is found mantling garnet (Fig. 2b), suggesting the progress of reaction (2):

$$
\mathrm{Grt}+\mathrm{Qtz}=\mathrm{Opx} 3+\mathrm{Crd}
$$

It has to be noted that both reactions (1) and (2) are not balanced and are therefore qualitative as cordierite contains minor volatile phases such as $\mathrm{H}_{2} \mathrm{O}$ and $\mathrm{CO}_{2}$. Similar microstructures developed through the progress of reaction (2) have been observed from many granulite terranes and has been considered to be an evidence of decompression (Harley, 1989). A possible prograde to peak assemblage is therefore inferred to be Opx $1+\mathrm{Spr} 1+$ Grt. Such porphyroblastic Opx1 is $\mathrm{Al}$-rich $\left(\mathrm{Al}_{2} \mathrm{O}_{3}=8.1-8.3\right.$ wt\%) when compared to the symplectitic Opx3 (7.2-7.5 wt\%), although their $X_{\mathrm{Mg}}[=\mathrm{Mg} /(\mathrm{Fe}+\mathrm{Mg})]$ ratios are similar $(0.70-0.72)$. Fine-grained orthopyroxene inclusions $(\mathrm{Opx} 2)$ in porphyroblastic sapphirine ( $\mathrm{Spr} 1)$ show intermediate $\mathrm{Al}$ content of $\mathrm{Al}_{2} \mathrm{O}_{3}=7.4-7.9$. In contrast, there is no significant compositional difference between Spr1 and Spr2. They are all Mg-rich (0.79-0.81) and characterized by slightly higher $\mathrm{Fe}^{3+}$ content $\left[\mathrm{Fe}^{3+} /\left(\mathrm{Fe}^{2+}+\right.\right.$ $\left.\mathrm{Fe}^{3+}\right)=0.26-0.39$ ] than the previous reports (e.g., Sajeev et al., 2004). Other components such as $\mathrm{Cr}_{2} \mathrm{O}_{3}(0.03-0.11$ wt $\%)$ are minor.

Although quartz is absent in the matrix of the rock, we found rare quartz grains enclosed in porphyroblastic Spr1 (Figs. 2c and 2d). Rutile, Opx2, biotite, and albite $\left(\mathrm{Ab}_{97-99}\right)$ are also included in the same sapphirine either as composite or as isolated inclusions. The quartz is fine grained $(<0.1 \mathrm{~mm})$ and shows direct contact relationship with Spr1 without any reaction texture between them (Fig. $3)$. Biotite and kornerupine surround the porphyroblastic Spr1 and are therefore regarded as products of post-peak retrograde stage (Fig. 2c), which is consistent with the observation of Sajeev et al. (2004). Compositionally, the biotite is rich in $\mathrm{Mg}\left(X_{\mathrm{Mg}}=0.72-0.73\right)$ and $\mathrm{Ti}\left(\mathrm{TiO}_{2}=\right.$ $4.3-4.6 \mathrm{wt} \%$ ). There is no significant compositional variation in biotite throughout the examined sample. Kornerupine is also Mg-rich with $X_{\mathrm{Mg}}=0.76-0.78$. Other components such as $\mathrm{TiO}_{2}(0.13-0.17 \mathrm{wt} \%)$ and $\mathrm{MnO}(0.11-0.18$ $\mathrm{wt} \%)$ in the mineral are minor.

\section{DISCUSSION}

This is the first report of equilibrium sapphirine + quartz assemblage from the classic UHT granulite locality Ganguvarpatti in the central Madurai Block, and the second report of this microstructure from the Southern Indian Granulite Terrane. Occurrence of texturally equilibrium sapphirine + quartz has been regarded as a robust evidence of UHT metamorphism at $T>1000{ }^{\circ} \mathrm{C}$ (e.g., Kelsey et al., 2004). Although post-peak decompressional $P-T$ path of Ganguvarpatti locality is well established by detailed petrological study of Sajeev et al. (2004) and Tamashiro et al. (2004) based on KFMASH petrogenetic grid, Al-in-orthopyroxene isopleth, mineral assemblages, compositions, and reaction microstructures, the peak $P-T$ condition was not established because of the absence of appropriate mineral assemblages. As the matrix porphyroblastic Sprl associated with quartz in the present sample is coarser in grain size than the retrograde symplectitic $\mathrm{Spr} 2$ with Opx3 and cordierite, and as Opx2 inclusion in the porphyroblastic $\mathrm{Spr} 1$ is more $\mathrm{Al}$-rich $\left(\mathrm{Al}_{2} \mathrm{O}_{3}=7.4-7.9\right.$ wt $\%)$ than symplectic $\mathrm{Opx} 3\left(\mathrm{Al}_{2} \mathrm{O}_{3}=7.2-7.5 \mathrm{wt} \%\right)$ with Spr2, we infer that Spr1 + Qtz assemblage predates all the decompression textures. The equilibrium stage of Spr1+ Qtz is therefore most probably higher $P$ and $T$ than the $[\mathrm{Bt}, \mathrm{Kfs}, \mathrm{Spl}]$ invariant point in Figure 4 (approximately $1005{ }^{\circ} \mathrm{C}$ and $7.7 \mathrm{kbar}$ ). Our results therefore confirm that the temperatures of peak metamorphism at Ganguvarpatti exceeded $1000{ }^{\circ} \mathrm{C}$, although we cannot neglect a possible effect of some minor elements such as $\mathrm{Fe}^{3+}, \mathrm{Cr}$, and $\mathrm{Be}$ in sapphirine, which could lower the temperature of stability of sapphirine + quartz (e.g., Kelsey, 2008). The results is consistent with previous estimates of the highest temperature condition of $1000 \pm 50^{\circ} \mathrm{C}$ and $11 \mathrm{kbar}$ (Sajeev et al., 2004) or even $T>1100{ }^{\circ} \mathrm{C}$ (Tamashiro et al., 2004), 


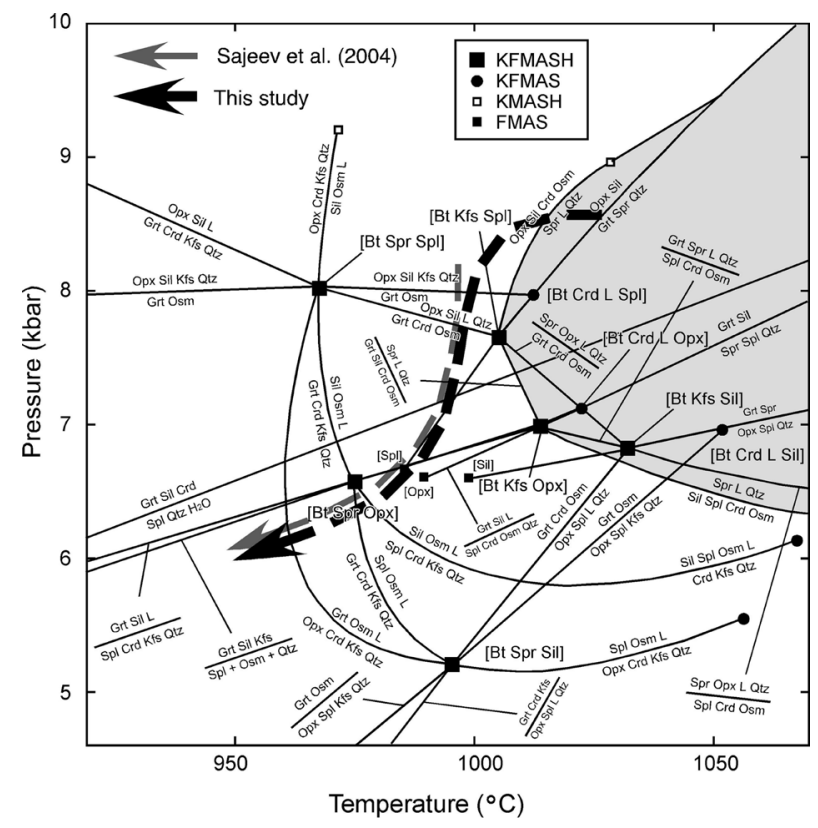

Figure 4. $P-T$ diagram showing revised $P-T$ path (black arrow) of Ganguvarpatti based on KFMASH petrogenetic grid of Kelsey et al. (2004) and petrological data of Sajeev et al. (2004). $P-T$ path of Sajeev et al. (2004) (gray arrow) is also shown in the figure for comparison.

which probably corresponds to a near-peak condition of Ganguvarpatti. Based on the new finding of sapphirine + quartz, we make an attempt to revise the $P-T$ path of Ganguvarpatti using the KFMASH petrogenetic grid of Kelsey et al. (2004) (Fig. 4). The peak metamorphic condition within the stability field of sapphirine + quartz was probably followed by isobaric cooling toward the stability field of orthopyroxene + sillimanite + quartz as inferred by Sajeev et al. (2004) (Fig. 4). As sapphirine + quartz and orthopyroxene + sillimanite + quartz were observed in different samples, we do not exclude a possible alternative interpretation that this might be due to the different bulk-rock chemistry. The two diagnostic UHT assemblages might have formed together within the overlapping stability field of the two assemblages; about $1020^{\circ} \mathrm{C}$ and 8.5 kbar (Fig. 4). Opx3 + Spr $2+$ Crd and Opx $3+$ Crd symplectites in the examined samples probably formed by decompression during the exhumation stage. The $P-T$ path shown in Figure 4 is nearly consistent with that presented by Sajeev et al. (2004) using a different petrogenetic grid, although our path starts from the stability field of sapphirine + quartz as inferred by Tamashiro et al. (2004). Our results therefore confirm post-peak isobaric cooling and subsequent decompressional $P-T$ trajectory of Ganguvarpatti.

Recently Santosh et al. (2009b) interpreted the evolution of the SGT by a progressive sequence from Pacifictype subduction-accretion orogeny to Himalayan-type collisional orogeny, and regarded the Madurai Block as a long-lived Neoproterozoic magmatic arc with accretionary belts and exhumed hot orogens. Our finding of the diagnostic evidence for UHT metamorphism from the central part of Madurai Block confirms this model as it suggests a number of extruded UHT metamorphic orogens within an accretionary package, similar to the situation in Pacific-type orogenic belts. Our study thus provides further support for the formation and exhumation of ultra-hot orogenic belts during the amalgamation of the Gondwana supercontinent.

\section{ACKNOWLEDGMENTS}

We thank the staff at Gondwana Research Office in Trivandrum and Ms. Preetha Warrier for their helpful support, and Dr. N. Nishida for his assistance on microprobe analyses. We also thank Dr. T. Hokada and Dr. K. Sajeev for their review comments and Dr. M. Satish-Kumar for his editorial handling. This is a contribution to the Grantin-Aid from the Japanese Ministry of Education, Sports, Culture, Science and Technology to Tsunogae (No. 20340148) and Prof. Osanai (No. 21253008), and JSPSINSA joint research program (No. BDD20023).

\section{DEPOSITORY AND SUPPLEMENTARY MATERIALS}

Table 1 and color version of Figure 2 are available online from http://www.jstage.jst.go.jp/browse/jmps.

\section{REFERENCES}

Bertrand, P., Ellis, D.J. and Green, D.H. (1991) The stability of sapphirine-quartz and hypersthene-sillimanite-quartz assemblages: an experimental investigation in the system $\mathrm{FeO}-$ $\mathrm{MgO}-\mathrm{Al}_{2} \mathrm{O}_{3}-\mathrm{SiO}_{2}$ under $\mathrm{H}_{2} \mathrm{O}$ and $\mathrm{CO}_{2}$ conditions. Contribution to Mineralogy and Petrology, 108, 55-71.

Braun, I., Cenki-Tok, B., Paquette, J.-L. and Tiepolo, M. (2007) Petrology and $\mathrm{U}-\mathrm{Th}-\mathrm{Pb}$ geochronology of the sapphirinequartz-bearing metapelites from Rajapalayam, Madurai Block, Southern India: evidence for polyphase Neoproterozoic high-grade metamorphism. Chemical Geology, 241, 129-147.

Collins, A.S., Santosh, M., Braun, I. and Clark, C. (2007) Age and sedimentary provenance of the Southern Granulites, South India: U-Th-Pb SHRIMP secondary ion mass spectrometry. Precambrian Research, 155, 125-138.

Harley, S.L. (1989) The origin of granulites: a metamorphic perspective. Geological Magazine, 126, 215-247.

Harley, S.L. (1998) On the occurrence and characterization of ultrahigh-temperature crustal metamorphism. In What Drives Metamorphism and Metamorphic Reactions (Treloar P.J. and O'Brian P.J. Eds.). pp. 287, Geological Society of London, Special Publication, 138, 81-107. 
Hensen, B.J. and Green, D.H. (1973) Experimental study of the stability of cordierite and garnet in pelitic compositions at high pressures and temperatures. III. Synthesis of experimental data and geological applications. Contribution to Mineralogy and Petrology, 38, 151-166.

Ishii, S., Tsunogae, T. and Santosh, M. (2006) Ultrahigh-temperature metamorphism in the Achankovil Zone: implications for the correlation of crustal blocks in southern India. Gondwana Research, 10, 99-114.

Kelsey, D.E. (2008) On ultrahigh-temperature crustal metamorphism. Gondwana Research, 13, 1-29.

Kelsey, D.E., White, R.W., Holland, T.J.B. and Powell, R. (2004) Calculated phase equilibria in $\mathrm{K}_{2} \mathrm{O}-\mathrm{FeO}-\mathrm{MgO}-\mathrm{Al}_{2} \mathrm{O}_{3}-\mathrm{SiO}_{2}-$ $\mathrm{H}_{2} \mathrm{O}$ for sapphirine-quartz-bearing mineral assemblages. Journal of Metamorphic Geology, 22, 559-578.

Mohan, A., Lal, R.K. and Ackermand, D. (1985) Granulites of Ganguvarpatti, Madurai District, Tamil Nadu. Indian Journal of Earth Sciences, 12, 255-278.

Morimoto, T., Santosh, M., Tsunogae, T. and Yoshimura, Y. (2004) Spinel + quartz association from the Kerala khondalites, southern India: evidence for ultrahigh-temperature metamorphism. Journal of Mineralogical and Petrological Sciences, 99, 257-278.

Sajeev, K. and Osanai, Y. (2004) Ultrahigh-temperature metamorphism $\left(1150{ }^{\circ} \mathrm{C}, 12 \mathrm{kbar}\right)$ and multistage evolution of $\mathrm{Mg}^{-}$, Al-rich granulites from the Central Highland Complex, Sri Lanka. Journal of Petrology, 45, 1821-1844.

Sajeev, K., Osanai, Y. and Santosh, M. (2004) Ultrahigh-temperature metamorphism followed by two-stage decompression of garnet-orthopyroxene-sillimanite granulites from Ganguvarpatti, Madurai block, southern India. Contributions to Mineralogy and Petrology, 148, 29-46.

Santosh, M., Yokoyama, S., Biju-Sekhar, S. and Rogers, J.J.W. (2003) Multiple tectonothermal events in the granulite blocks of Southern India revealed from EPMA dating: implications on the history of supercontinents. Gondwana Research, 6, 29-63.

Santosh, M., Collins, A.S., Tamashiro, I., Koshimoto, S., Tsutsumi, Y. and Yokoyama, K. (2006) The timing of ultrahightemperature metamorphism in Southern India: U-Th- $\mathrm{Pb}$ electron microprobe ages from zircon and monazite in sapphirine-bearing granulites. Gondwana Research, 10, 128-155.

Santosh, M., Tsunogae, T., Li, J.H. and Liu, S.J. (2007) Discovery of sapphirine-bearing $\mathrm{Mg}-\mathrm{Al}$ granulites in the North China Craton: Implications for Paleoproterozoic ultrahigh temperature metamorphism. Gondwana Research, 11, 263-285.

Santosh, M. and Omori, S. (2008) $\mathrm{CO}_{2}$ windows from mantle to atmosphere: Models on ultrahigh-temperature metamorphism and speculations on the link with melting of snowball Earth. Gondwana Research, 14, 82-96.

Santosh, M., Maruyama, S. and Yamamoto, S. (2009a). The making and breaking of supercontinents: Some speculations based on superplumes, superdownwelling and the role of tec- tosphere. Gondwana Research, 15, 324-341.

Santosh, M., Maruyama, S. and Sato, K. (2009b) Anatomy of a Cambrian suture in Gondwana: Pacific-type orogeny in southern India? Gondwana Research, 16, 321-341.

Shimizu, H., Tsunogae, T. and Santosh, M. (2009) Spinel + quartz assemblage in granulites from the Achankovil Shear Zone, southern India: implications for ultrahigh-temperature metamorphism. Journal of Asian Earth Sciences, 36, 209-222.

Spear, F.S. (1993) Metamorphic phase equilibria and pressuretemperature-time paths. MONOGRAPH, pp. 799, Mineralogical Society of America, Washington, D.C.

Tadokoro, H., Tsunogae, T., Santosh, M. and Yoshimura, Y. (2007) First report of the spinel + quartz assemblage from Kodaikanal in the Madurai Block, southern India: implications for ultrahigh-temperature metamorphism. International Geology Review, 49, 1050-1068.

Tadokoro, H., Tsunogae, T. and Santosh, M. (2008) Metamorphic $P-T$ path of the eastern Trivandrum Granulite Block, southern India: implications for regional correlation of lower crustal fragments. Journal of Mineralogical and Petrological Sciences, 103, 279-284.

Tamashiro, I., Santosh, M., Sajeev, K., Morimoto, T. and Tsunogae, T. (2004) Multistage orthopyroxene formation in ultrahigh-temperature granulites of Ganguvarpatti, southern India: implications for complex metamorphic evolution during Gondwana assembly. Journal of Mineralogical and Petrological Sciences, 99, 279-297.

Tateishi, K., Tsunogae, T., Santosh, M. and Janardhan, A.S. (2004) First report of sapphirine + quartz assemblage from southern India: implications for ultrahigh-temperature metamorphism. Gondwana Research, 7, 899-912.

Tsunogae, T. and Santosh, M. (2006) Spinel-sapphirine-quartz bearing composite inclusion within garnet from an ultrahightemperature pelitic granulite: implications for metamorphic history and $P-T$ path. Lithos, 92, 524-536.

Tsunogae, T., Santosh, M., Ohyama, H. and Sato, K. (2008a) High-pressure and ultrahigh- temperature metamorphism at Komateri, northern Madurai Block, southern India. Journal of Asian Earth Sciences, 33, 395-413.

Tsunogae, T., Santosh, M. and Dubessy, J. (2008b) Fluid characteristics of high- to ultrahigh-temperature metamorphism in southern India: a quantitative Raman spectroscopic study. Precambrian Research, 162, 198-211.

Tsunogae, T. and Santosh, M. (2009) Ultrahigh-temperature metamorphism and decompression history of sapphirine granulites from Rajapalaiyam, southern India: implications for the formation of hot orogens during Gondwana assembly. Geological Magazine, doi:10.1017/S0016756809990100.

Manuscript received June 7, 2009

Manuscript accepted July 27, 2009

Manuscript handled by M. Satish-Kumar 